\title{
The Colony of Aden in Post-Colonial Yemeni Novel
}

\author{
M. N. Suvorov \\ St. Petersburg State University, \\ 7-9, Universitetskaya nab., St. Petersburg, 199034, Russian Federation
}

For citation: Suvorov M.N. The Colony of Aden in Post-Colonial Yemeni Novel. Vestnik of Saint Petersburg University. Asian and African Studies, 2021, vol. 13, issue 1, pp. 32-50.

https://doi.org/10.21638/spbu13.2021.103

In many Arab countries, where colonial rule was replaced by local authoritarian, often corrupt, regimes, popular discontent with the living conditions under the new government has produced a kind of nostalgia for the colonial past. This nostalgia is well observed in today's Aden (Republic of Yemen), which was a British colony from 1839 until 1967. In the middle of the $20^{\text {th }}$ century, Aden was the most prosperous city on the Arabian Peninsula and one of the busiest seaports in the world. This article examines how this nostalgia is manifested in modern Yemeni literature, namely in three novels: Three Midnighters (1993) by Sa'id Awlaqi, Adeni Incense (2014) by Ali al-Muqri, and Steamer Point (2015) by Ahmad Zayn (Zein). In the novel Three Midnighters, which takes place in the late 1980s, the allegory of Aden Colony is a cultural club, whose activities are remembered by the characters. The main characteristics of that club were its openness to all people, its atmosphere of freedom of thought, freedom of expression, mutual respect of its members, prosperity, love, and fun. In Adeni Incense, Aden Colony also resembles a wonderful club. The members of this club, that is, the characters of the novel, live in harmony, love, and prosperity - until evil external forces begin to destroy this club. The lack of realistic details in the depiction of the city and its inhabitants allows the reader to perceive the novel as allegorical rather than realistic. In Steamer Point, Aden Colony does not appear as a wonderful club, since the novel is written in a completely realistic manner. Nevertheless, Aden in the novel has two important features: the economic prosperity and peaceful coexistence of representatives of different cultures and different identities. It is these features of the city that one of the main characters, a sincere admirer of the British, is afraid to lose as a result of the British withdrawal.

Keywords: Arab novel, Yemen, Aden, Said Awlaqi, Ali al-Muqri, Ahmad Zein.

In his book Arab Representations of the Occident: East-West encounters in Arabic fiction (2006) Rasheed El-Enany, a British scholar of Egyptian origin, wrote:

"The heady years of national self-confidence in the early post-independence period were, however, not to endure. The turning point was the humiliating Arab defeat in the 1967 war with Israel. Arab intellectuals did not see the defeat in only military terms, but were to see it in the fullness of time as a symptom of the collapse of the national dream in the post-independence era. Colonial rule was gone, but in its place what emerged was not democracy, liberalism, and the welfare state, but rather autocratic governments that repressed individuals and groups, often more fiercely than under colonialism, and disastrous policies that led to military defeats and economic decline. There was a sense of pervasive national disillusionment.

(C) St. Petersburg State University, 2021 
This new sombre mood was inevitably to lead to a reassessment of both self and other; a reassessment in which on this occasion and for the first time the other was to be shown as ethically superior to the self: Arab intellectuals had come a long way since the days of the materialistic, morally corrupt West versus the spiritual East" [1, p. 113].

Indeed, this "new sombre mood" in many parts of the post-colonial (or post-independence) Arab world produced a kind of nostalgia - though rarely articulated openly for the colonial days or, better, for what Veronica Della Dora defined as "transnational culture and its expressions in provincial cosmopolitanism" [2, p. 207].

Among these parts there is Aden, the second largest city of the Republic of Yemen and a former British colony. Kevin Alexander Davis, who did a field study of collective memory in Aden in 2013, wrote:

"The decaying infrastructure and the erosion of the built environment of Aden was a constant topic of discussion for the residents I spoke with. The contrast between Aden's prosperous past and its current state of disrepair was a constant rallying call for those demanding a return to a two-state political order ${ }^{1}$. Khaled and many others referred to the history of the British as a time of prosperity for South Yemen. It was the British who began to build schools, hospitals, and roads throughout the south, ushering in rapid development and modernization. A new idealization of the British era was being constructed in the context of what Khaled was showing me: abandoned schools, roads in desperate need of repair, and a very visible sense of poverty" [3, p.23].

"One particular photograph that had been circulated at rallies, as well as through social media was a picture of Aden in the 1950s compared with a picture of the city today. The two extremes were easily visible, with the older picture showing a bustling ocean ship terminal, well-dressed businessmen from diverse origins, and large colonial era hotels. The contemporary picture depicted an Aden that was falling apart, with collapsed buildings, broken vehicles, and ragged-looking Adenis begging on the streets" [3, p. 30 $]^{2}$.

"Historical remembrance was not only focused on large-scale administrative projects and economic prosperity, but by a sense of cosmopolitanism and urbanism that is felt by many Adenis. $\langle\ldots\rangle$ As population figures show for the period of British rule, Aden was cosmopolitan in its social makeup of diverse ethnic, religious, and linguistic groups. As a product of collective memory, cosmopolitanism is an ethical ideal implicated in the process of cultural difference making. The southern vision of cosmopolitanism rejects and confronts cultural superiority and ethnocentrism as associated with the larger northern occupation project ${ }^{3}$. The idea of cosmopolitanism rather espouses diversity and multiculturalism as achievements of a southern collective mentality" [3, p. 33-34].

While K. A. Davis presented in his work various manifestations of Adenis' nostalgia for the British era with its cosmopolitanism as they appear in today's oral discourse, my aim in this article is to analyze how this nostalgia is manifested (if it really is) in post-colonial Yemeni fiction literature. For this analysis I've chosen three novels - simply because these three novels seem to be the only ones in modern Yemeni fiction that are devoted to the time of the British rule in South Yemen or refer to it. These novels are:

${ }^{1}$ Before unification in 1990, Yemen was divided into two independent states (note by M. Suvorov).

${ }^{2}$ K. A. Davis also refers to a website containing a lot of photos of Aden Colony: http://alamree.net/ alboums_main.htm

${ }^{3}$ By northern occupation project K. A. Davis means northern-Yemenis' hegemony in today's Yemen as perceived by the southerners. 
Three Midnighters (al-Summār al-thalātha, 1993) by Sa'id Awlaqi (b. 1946), Adeni Incense (Bakhūr 'adanī, 2014) by Ali al-Muqri (b. 1966), and Steamer Point ${ }^{4}$ (Stīmir būynt, 2015) by Ahmad Zayn (b. 1968).

In order for the reader to better understand the historical context of what the three novels are about, it would be appropriate to give a brief account of what Aden, a British colony since 1839 , was and what was going on in the city in the $1940-60 \mathrm{~s}^{5}$. I will also say a few words about how Aden was depicted in Yemeni literature in those years.

The Colony of Aden, the largest seaport on the Arabian Peninsula, was not an Arab city, but a cosmopolitan one. Its population consisted of Arabs, Indians, Europeans, Jews, Somalis, Persians, and representatives of many other peoples. As an administrative unit of the British Empire, Aden until 1937 was subordinate to the British Viceroy of India, and the proportion of Indians in the city's population steadily increased throughout the first half of the $20^{\text {th }}$ century. In the early 1930 s, Indians accounted for about $40 \%$ of the total population. The influx of Indians was also facilitated by the British authorities themselves, who were eager to employ them in city government offices. According to many accounts of the time, Aden in those years was more like an Indian city, and Arabic was not the most audible language on its streets.

By the mid-1950s, Aden's importance as a fueling and supply station for ships plying between Europe and the Far East had grown so much that it became one of the world's busiest ports. The duty-free trade regime introduced in Aden also contributed to the economic development of the city. The British government, soon after losing military bases in Egypt in 1956 and in Iraq in 1958, designated Aden the permanent headquarters of Britain's Middle East Command, which operated army, navy, and air force.

In the ten years following the end of WWII, the population of Aden had grown by more than one and half times. Native Adenis made up just a little over a quarter of the city's population, while labor migrants from North Yemen, as well as from South Yemeni sultanates and sheikhdoms, made up more than a third of it. Yemeni migrants, poor, illiterate people, performed unskilled work in the port, on the British military base, in the construction and service sectors. They were sending most of their meager earnings to their families back home. The migrants lived, as a rule, in dormitories and temporary barracks, with many people in one room, or in shanties constructed of improvised rubbish. Their situation in the city was not stable: having lost their jobs, they left Aden for home, but soon returned in search of new earnings.

Overpopulation, fierce competition for earnings, and the growing gap between rich and poor provided fertile ground for the spread of radical revolutionary ideas in Aden in the second half of the 1950s. By that time, independent Egypt with President Nasser at its head presented the ideal for the entire Arab world. Since the early 1960s, the propaganda broadcasts of the Egyptian radio "Voice of the Arabs" reached every corner of the Arab world - thanks to the spread of inexpensive transistor radio receivers affordable even for

${ }^{4}$ Steamer Point is the name of a district in Aden, which was inhabited mainly by Europeans in the colonial era.

${ }^{5}$ For more detail about Aden Colony in the 1940-60s see [4, p. 58-62, 71-77, 96-102, 108-114; 5, p. 65-88]. 
the poor. The Arabs in Aden and in South Yemeni sultanates and sheikhdoms were being convinced that their land remains the last Arab territory on which the British rule.

Nationalist, anti-colonial ideology was rapidly finding a following among Arab workers and employees in Aden, many of them being members of trade unions. Political groups, parties and blocks were being formed, with different political objectives. In 1963, with the support of the Egyptians, who were involved in the civil war in North Yemen (1962-1970) on the side of the Republicans, the National Liberation Front (NLF) was formed, whose aim was to expel the British from South Yemen. The same year, a guerrilla war against the British began on the territory of South Yemeni sultanates and sheikhdoms, which by that time had been united in a Federation of South Arabia, supported by the British government. The guerrilla war soon spread to Aden. In the face of almost daily terrorist attacks, the British repeatedly imposed the state of emergency in the city, but the situation only worsened. Anti-terrorist raids and arrests in Aden (which joined the Federation in 1962) and bombing rebels in South Yemeni province did not give tangible results. In 1966 the British government decided to grant the Federation full independence and evacuate British military base in Aden. In summer of 1967, the fighting was no longer between the Arabs and the British, but between two revolutionary Arab groups: NLF and the Front for the Liberation of the Occupied South Yemen (FLOSI, formed in 1965). On November 29 of the same year, the last British military units left Aden, and the Federation, which plunged into political chaos, ceased to exist.

The turbulent socio-political situation in Aden in the second half of the 1950s and in the 1960s found its reflection in Yemeni fiction of that time, which in those years was being written and published exclusively in Aden. It is noteworthy that Aden does not appear in this literature as a flourishing city full of modern goods and services, but rather as a scene of blatant social stratification, racial inequality, class exploitation, violence by the British authorities, and resistance to this violence by citizens. All this can be found in such collections of short stories as The Torn Ultimatum (Al-Indhār al-mumazzaq, 1960) by Ahmad Mahfuz Umar, Self-denial (Dhawbān al-dhāt, 1965) by Muhammad Qasim Muthanna, Volcano Eruption (Thawrat al-burkān, 1968) by Abdallah Salim Bawazir, No Entry! (Mamnū' al-dukhūl, 1968) by Ali Badhib, The Sign (Al-Lāfita, 1978) by Kamal Haydar, A Dove in a Hawk's Nest (Hamāma fí 'ushsh șaqr, 1989) by Abd al-Majid al-Qadi and in the novels Cart Horse (Hișān al-'araba, 1959) and A Worker's diary (Mudhakkirāt 'āmil, 1966) by Ali Muhammad Abduh 6 .

Immediately after the evacuation of the British, life in Aden dramatically changed. The newly independent South Yemen found itself in an extremely difficult economic situation. The port of Aden, formerly the country's main source of income, lost its importance after the Suez Canal was closed as a result of the Arab-Israeli war. The withdrawal of the British military base from Aden deprived the national economy of the annual income of approximately 15 million pounds. Following the British, representatives of the non-Arab population and migrants from North Yemen, totaling more than 80 thousand people, left Aden. In place of those who left, thousands of tribesmen arrived from the countryside, in the eyes of native Adenis savage "Bedouins", eager to take advantage of the "revolutionary achievements" in order to get their share of the expected benefits of urban civilization. In the face of the acute economic crisis, the leaders of the left wing of NLF, who came to

\footnotetext{
${ }^{6}$ About these works see [6, p. 76-94].
} 
power on June 22, 1969, chose Marxism as their state ideology, counting on the support of the countries of the socialist camp. A year later, the country received a new name - the People's Democratic Republic of Yemen (PDRY).

Very soon the new Marxist regime's repressive domestic policy, which was pursued in the situation of the country's economic decline and commodity shortage, produced the "new sombre mood". For native Adenis, memories of flourishing Aden Colony, as a pleasant contrast to the socialist Aden, increasingly developed into a kind of nostalgia. Writing about this contrast was dangerous, and for this reason one can hardly find in Yemeni literature of the 1970-80s any clear image of either Aden Colony or the socialist Aden.

A conflict in the political leadership of PDRY resulted in a bloody fight in 1986, which terminated South Yemenis' hopes for a better socialist future and became the starting point of the process of unification of South Yemen with North Yemen. The process was completed in 1990, and the united Republic of Yemen, devoid for a while of clear ideological guidelines, allowed both South Yemeni and North Yemeni authors to undertake a rethinking of Yemen's recent history. It was at this time that Sa'id Awlaqi's novel Three Midnighters was published. The other two novels, Ali al-Muqri's Adeni Incense and Ahmad Zayn's Steamer Point, appeared much later, when the spread of Islamism, which replaced the socialist ideology in the southern part of the country and was suppressing all manifestations of secularism, made the intellectuals' mood even more sombre.

Sa'id Awlaqi's novel Three Midnighters takes place in Aden in the late 1980s. The main storyline in the novel is reduced to one episode in the life of three friends: the publicist and poet Ahmad al-Qadi, the composer Anwar Khan and the theater director Mahdi Basunbul, who have a habit of meeting together in the evenings near the building of a former cultural club in Aden, of which they used to be regular visitors. In conversations, friends often spend the entire night, and this is why they received the nickname "midnighters". One night, all three are detained by the police. At the police department, an officer named Jubran insists that they testify that a certain person accused of murder was in their company on the night of the murder and therefore was not involved in the murder. Jubran uses threats to make three friends agree to give the required evidence in court. However, in the courtroom, each of them, unable to suppress the voice of conscience, tells the truth. The novel ends with midnighters fearfully waiting for revenge from Jubran and pondering their uncertain future.

This main storyline is interspersed with memories of friends about their past, about events in the life of the country that they witnessed. The novel thus covers a significant period in the history of Aden and all of South Yemen, from the early 1950s to the late 1980s. In midnighters' memoirs, many features of the social and political life in PDRY are vividly presented, such as hammering of ideological cliches into the heads, political censorship and persecution of dissenters, the commodity shortage and the atmosphere of fear.

Many specific details in the novel - well-known events, names of political figures, names of districts, streets and coffee shops in Aden, and even the biographies of the main characters, whose prototypes are, apparently, certain popular cultural figures in Aden, give the story a touch of documentality.

This documentality, however, gets along in the novel with masterful use of allegory. One example of this is the image of the cultural club, which has become the meeting place 
for midnighters. One of the cultural clubs founded in Aden by Arab enlighteners during the British rule was actually located in $\mathrm{Crater}^{7}$, the oldest district of the city, in the very place indicated in the novel. The club's activities in the past were exactly as described in the novel. At the same time, the history of the club in the novel serves as an allegory of the modern history of Aden itself:

"When the cultural club located on Queen Arwa street in Aden was at the height of its splendor and brilliance, its days and nights witnessed the most beautiful events in this old city, which rests surrounded by a chain of high, barren mountains.

Here, over the years, hundreds of meters of $q a t^{8}$ branches were stripped, hundreds of thousands of bottles of Coca-Cola were opened, and as many sheep were skinned as could make up a whole flock. As for the various drinks drunk here, they would have been enough for a small lake.

Here musical evenings, dances, performances and film screenings possessed their own taste, and their visitors possessed their temperament, and their traditions possessed their sanctity. And these evenings had such a status that their noise did not echo badly afterwards.

Here laughter rang freely, filling the space, and tears shyly hid in handkerchiefs, here lights shone, floating in the darkness of the night, and songs and melodies soared happily, breaking through the blockade by the mountains, blockade by silence, blockade by fear.

Everything here had the taste, the smells were fragrant, the words carried the sense, the hearts beat and love blazed. It was the gathering place for leaders, ministers, members of cabinets and commissions, rulers, governors, ambassadors, judges, executioners, lawyers, defendants, witnesses, policemen, thieves, conspirators, spies, traitors, honest people and murderers.

Within the walls of this ancient club, at its evenings, no one ever thought to doubt that all those present rightfully belong to the human race..." [7, p. 3-4 $]^{9}$.

With this brief description of the club's former life, the author conveys the free social atmosphere, which prevailed in cosmopolitan Aden Colony. Then different times came for the club: many emigrated, some took important government positions and stopped going to the club, others died or were killed. In the end, the club simply ceased to exist.

"Many longed for the beautiful and simple past, to which they were accustomed, which they understood and loved", the author continues. "They were not happy with the rough, cruel present, which forbade memories and did not provide consolation. They also did not believe in future, having lost all desire to become a part of it" [7, p.7].

The above passage accurately conveys the atmosphere of fear and pessimism, which became characteristic of public life in PDRY.

In the end of the novel, which speaks about the late 1980s, when the South Yemeni government began to look for a new way to develop the country and intensified negotiations with North Yemen on unification, the idea of restoring the club appears:

7 About Adeni Arab enlighteners' activities see [6, p. 35-41]. The name Crater was given to the district by Europeans because it is located in the crater of an extinct volcano. As for the Arabs, they call the district simply Aden.

${ }^{8}$ Qat (Catha edulis) is a plant of light narcotic properties, chewing the leaves of which in the company of friends has long been a kind of social habit in Yemen, the main way of socialization (note by M. Suvorov).

9 This and the following citations are translated from Arabic by the author of the article. 
"Over the past months, attempts have continued to restore the club, which has fallen into a state of complete ruin during the years of neglect. People began to try to understand the causes of this desolation, to find possible solutions to the problem in the light of a new understanding of the situation. Some measures were taken to put an end to the desolation of the club and, if possible, to make it look welcoming to its members, guests, and other visitors.

There were arguments about how to restore the club, about the feasibility of this undertaking, about possible consequences and unforeseen situations. The state in which the club came during its inactivity was so terrible that repairs were the only way to save it from final destruction..." [7, p. 103-104].

In reality, as soon became clear to everyone, the "restoration of the club" after the unification of Yemen did not happen: the Marxist dictatorship was replaced by military-tribal and Islamist domination.

The representation of cosmopolitan Aden Colony in the image of a club that is open to all and gives pleasure to all one can also see in Ali al-Muqri's novel Adeni Incense. It seems that this image of Aden Colony is the main, and perhaps the only idea of the novel, in which any other idea is quite difficult to grasp.

The main character of the novel is a Frenchman who came to Aden during WWII, as a young man, and stayed there to live. The story is told on his behalf; he recounts his life in Aden from the time of his arrival to the end of the British colonial rule and the beginning of left-wing radical transformations in South Yemen in the late 1960s. The story focuses on his interactions with the residents of Aden, who belong to a variety of nationalities and faiths. They are mostly middle-class people: entrepreneurs, merchants, government officials, intellectuals, religious figures, singers, musicians, etc. There are so many of these characters in the novel, and they are all so impersonal, including the Frenchman himself, that it is difficult for the reader to keep in mind their names, occupations, and who they are to each other. A lot of attention in this story is paid to the interaction of different cultures in Aden (especially in song and music) and to love and marriage relations between representatives of different origins, nationalities and faiths, which is generally a favorite theme of al-Muqri ${ }^{10}$.

The novel consists of a huge number of episodes, arranged in small chapters. These episodes take place in casino "Bandar", in coffee shop "Zakku"11, in private homes and shops where all these characters meet. The main place of action is casino "Bandar", which is the club that symbolizes the whole of Aden, similar in this sense to the cultural club in Three Midnighters. In this casino, characters drink, socialize and watch musical groups' performances; as for gambling, the author does not mention it.

${ }^{10}$ His first novel Black Taste, Black Odour (Tám aswad, rā'iha sawdā', 2008) is devoted to love relations between representatives of different social strata in Yemen, and his second novel The Handsome Jew (Al-yahūdī al-hālīi, 2009) - to love relations between Arabs and Jews. About these novels see [8, p. 87$88 ; 9$, p. 61-63].

11 "Zakku" is the name of a real coffee shop that existed in Crater until 1994 and was very popular among Adenis. 
The conversations of the characters in most episodes are of a very private nature and do little to recreate the social atmosphere in Aden in the corresponding time. Any of these episodes-chapters can be removed from the novel without any damage to the plot. The exception is the few episodes in which the dispute concerns politics: they reflect to some extent the conflicting public opinions during the periods described.

Despite the novel mentioning a large number of the names of the city's real quarters, streets, markets, shops, hotels, coffee shops, cinemas, mosques, as well as the names of famous Adeni entrepreneurs (Bardey, Besse, Khan, Bhikaji, Sorabji, Mansharji, Bazara, etc.) and even the recognition of individual characters with real prototypes ${ }^{12}$, the "visual" image of the city and the city's life is almost absent. This is all the more surprising, given that the appearance of Aden has always been extremely expressive and very different from any other Arab city. Here is, for example, how its appearance in the 1950s is depicted in the memoirs of Donald Foster, a former British political adviser:

"For all the hard things that may be said about Aden there is no denying the dramatic impact of a first sight of it. Out of an ocean-dark sea it towers suddenly, seventeen hundred feet of naked rock, sharply conical to the peak of Shamsan. In a sea approach the curve of the sea horizon will at first conceal the buildings which circle the base of the mountain, so that it shows menacingly stark and unpeopled" [10, p. 13].

"Five elements make up the texture of Aden: first the rock, glowering and pulsing with heat, dominating every prospect, every vista; second the port, for the traditional entrepot trade, for the fuelling of ships - it handles 600 a month, third largest in the Commonwealth - and for the free-spending of a thousand tourists a day; third, the British; fourth, the hinterland - Yemen and the Protectorate ${ }^{13}$ - an unseen, pervasive, threatening presence; and fifth, the climate" [10, p. 14].

"An arc of shops circles a lush garden, towering with imported coconut-palms and bright with oleanders; Queen Victoria in bronze reigns from a white marble throne. The streets are crowded, pavements and shop-verandahs occupied by loafers hawking, spitting and shouting, by shopkeepers touting for custom - 'Johnny-Johnny - come 'ere very fine - I show you - special price for you - hey Johnny', by blind beggars led by children, by dhoti-clad Hindus of Parsee merchant houses, by policemen in dark-blue fezzes and by merchant seamen, not infrequently drunk, reeling and shouting about the pavements. Shops are packed with goods and there is no attempt at layout: everything that can be packed into the high-rent premises is jammed on to the shelves. The goods are all imported: the are no local artifacts, no craft-goods; the staples are cameras, watches, radios, record-players, binoculars, perfumes, projectors" [10, p. 14-15].

"Away from the gimcrack shops there is little of interest; the barren slopes rise abruptly from behind the Crescent ${ }^{14}$, frayed with a suburb of shanties crazily constructed of old packing cases and kerosene tins, where live the poor. These shanty-towns burgeon on any piece of waste ground, the constant housing shortage aggravated by a continual drift of Yemenis across the open frontier" [10, p. 15].

12 In particular, the prototype of the "Adeni philosopher" in the novel is undoubtedly a famous Adeni enlightener Muhammad Ali Luqman (1898-1966). About him see [6, p. 36-39, 46-51].

13 The Protectorate of South Arabia consisted of South Yemeni sultanates and sheikhdoms under treaties of protection with Britain (note by M. Suvorov).

${ }^{14}$ Crescent is a quarter in Steamer Point, named so after the "Crescent Hotel" located in this vicinity (note by M. Suvorov). 
"Behind the would-be-slick facades of the main road, and indeed showing nakedly through them, lies the teeming and dirty town - oriental, stinking, street-dwelling, over-crowded, with shanty-dwellers clinging to niches in the rocks, cots on every sidewalk where men sleep unconcerned, food stalls distantly spicy, proximately unspeakable, Hindu-holy cattle, chequered goats, fat-tailed sheep, curs, crows and rib-sticking gharry-ponies" [10, p. 20].

"Always the Crater streets are crowded, at all hours of day and night: local people in sloppy and unlovely costume - a vest and/or shirt both unbuttoned and usually dirty, waist-cloth of any length between ankle and knee and secured by a greasy webbing money-belt, rubber sandals, topped by a skull-cap or untidy turban; tall Somalis, dressed more neatly and arrogant in their bearing; ragged Yemenis newly from the highlands, in fringed black turbans and unspeakable shirts of striped flannel, close-buttoned under dirty whickers; long-gowned seamen from the dhows of Muscat and Kuwait and Bahrein. Tribesmen from the interior are identifiable by their turban-style or by subtle physiological distinctions - Fadhlis from Abyan in blue Rajput-style turbans; Audhalis with white head-cloths in a flat neat roll; wild Mahra, big-featured men from the wastes beyond Mukalla; pallid Hindus, insipidly but cleanly clad in white with black Gandhi caps, women hidden behind all-enveloping black clothes and coloured face-veils" [10, p. 22 $]^{15}$.

Al-Muqri's novel contains almost nothing of what is pictured in the fragments above. The novel, therefore, resembles a theater of faceless puppets that is completely devoid of scenery. A reader familiar with Aden may even get the impression that the author of the novel has never seen Aden with his own eyes, although this is certainly not the case.

The novel also lacks any articulated intrigue that would encourage the reader to continue reading. The author, however, makes some attempts to create an intrigue "artificially", but they are rather clumsy. For example, he tries to intrigue the reader with the question of who the main character of the novel really is. On behalf of the all-knowing narrator, which appears in some chapters of the novel, the author tells a story of two French classmates that took place in France during WWII. One of them, François, was looking for a way to avoid going to war, and the other, Michel, was eager to take up arms, but was unfit for military service because of a limp. Michel's parents were planning to send him to Aden, where he could get a job with the support of one of the relatives living there. François makes an attempt to steal Michel's documents, including the certificate of disability and the boat ticket to Aden, but Michel thwarts this attempt. A conversation takes place between the friends, after which one of them goes to Aden, and the other goes to war. Which of them came to Aden, the "all-knowing" narrator says, is unknown. The newcomer was limping, which means it could have been Michel, who had changed his orthopedic shoes for normal ones, or François, who had changed his shoes for Michel's orthopedic shoes. Anyway, upon his arrival in Aden, the protagonist decides to abandon his identity and takes the name Lashey, which in Arabic means "nothing". Throughout the story, Lashey repeatedly reflects on his identity, but the reader never knows who came to Aden: François or Michel. Luckily, nothing in the novel makes the reader want to know this.

Much of Lashey's reflection on his identity leads him to articulate what Aden is to him. Here is one of his conclusions:

${ }^{15}$ I quote so much of D. Foster's book not only to give the reader an idea of the peculiar and unique appearance of Aden, especially in the times of colony, but also to allow the reader to appreciate the accuracy of the depiction of Aden in the novel Steamer Point by Ahmad Zayn, which is discussed below. 
"During the year I spent in Aden, I began to consider it a refuge for all that is different. I don't want to say that Aden is a homeland for others or a homeland for those who don't have the homeland. But it began to seem to me that Aden can substitute everything, even the homeland, any homeland. It can even substitute the very idea of the homeland, substitute the homeland as an idea" [11, p. 142].

The second character after Lashey in terms of presence in the story is a woman of unknown nationality, who has a nickname Mama and lives in a Somali family. At the time of the protagonist's arrival in Aden, she is only 16 years old, but she is already everyone's favorite in the mentioned middle-class circles and has access to every home. Mama allegedly earns a living by accompanying tourists, but in this role the reader does not see her. She is simply present in most of the episodes in the role of everyone's favorite and organizer of parties. When uncle Sham un, the owner of the casino "Bandar", emigrates to Israel, he appoints Mama and Lashey as managers of his casino.

Mama is also known for having prophetic dreams. In particular, her dream that Queen Elizabeth II had a dream about Aden encourages all her friends to actively discuss the possibility of the Queen's visit to Aden and even to compose the text of the appropriate invitation for Her Majesty ${ }^{16}$. This is another "artificial" intrigue in the novel, by which the author tries to entertain the reader.

Unlike many other characters, Mama never marries anyone, although at the end of the novel she is more than forty years old. One may assume that the image of Mama in the novel is intended to symbolize Aden, which is adored by all and does not belong to one person or to one nation.

Yet another notable character and everyone's favorite in the novel is the Jewish woman Sham'a, a singer and director of a musical group. Performances of the group in the casino "Bandar" and at private parties are given a lot of space in the novel. Sham'a - clearly in contrast to Mama - has been the wife of almost every musician in her band, although the symbolic meaning of this detail of her biography (if, of course, there is any symbolic meaning) is not clear. Shama leaves Aden for good along with other Jews who emigrated from South Arabia to Israel in 1949.

The departure of Sham'a and other Jews from Aden is perhaps the most telling episode in the novel, or, better, a sequence of episodes beginning with the Jewish pogroms in Aden in 1947. This sequence of episodes becomes a turning point in the fate of Aden Colony as a "club", whose members used to be united by mutual sympathy, respect, international marriages and love affairs. Growing religious, national, and then class intolerance leads this "club" in the end of the novel to its complete disintegration. Most of its members flee, and among the remaining one part exterminates the other as a class enemy. This collapse symbolically ends with the explosion of the casino "Bandar" and the death of its last visitors and employees, including Mama, under its ruins.

One may assume that there is more of allegorical in al-Muqri's novel, than of realistic. Besides the fact that the writer did not show actual appearance of Aden, as well as the realities of its business, public and street life, he also ignored some notable events of the 195060s: trade unions' strikes and demonstrations, terrorist acts by NLF and counter-terrorist operations by the British security, the bloody conflict between NLF and FLOSI. Moreover,

${ }^{16}$ Queen Elizabeth II visited Aden in 1954, a year after her coronation. 
the novel does not show that any of the characters participated in these events or, at least, had any clear opinion about them.

Based on the above, one may conclude that the writer did not seek to create a realistic image of Aden Colony, but an image - in the spirit of the so-called "armchair nostalgia" - simply opposite to that sullen Aden, oppressed by Marxist regime and then by Islamists, that the city became in the post-colonial era.

Everything that the image of Aden Colony in Adeni Incense lacks to be realistic is fully present in Ahmad Zayn's novel Steamer Point. This is largely due to the author's specific manner of writing, which can be called "cinematic". Its essence lies in the fact that the text of the work is made up of a mosaic of "visually" written out disparate scenes, which the author arranges in such a way that their interaction causes the process of induction of meanings. At the same time, a consistent story about the events is almost absent; the intrigue may also be absent or not obvious. Often, the meaning of a scene becomes completely clear to the reader only after reading the subsequent scenes. To a greater or lesser extent, Ahmed Zayn used this manner in all his works, which made them, according to some critics, very difficult to perceive ${ }^{17}$.

In Steamer Point three storylines are clearly distinguished; each of them is divided into chapters, and all of these chapters are interspersed.

The central storyline, which occupies more than a third of the volume of the text, chronologically represents the culminating episode of the entire narrative. The episode is divided into six chapters; the novel begins with the first of these, and ends with the last. This episode is localized in the house of a famous Adeni merchant, French by origin. In terms of time, the episode covers the evening of November 28, 1967 and the early morning of the next day - the day when the last British military withdrew from Aden. The prototype of the merchant, who in the novel is referred to simply as "the Frenchman" or "the old man", is undoubtedly Antonin Besse (1877-1951), whose life story itself can serve an illustration of the history of socio-economic development of Aden Colony in the $20^{\text {th }}$ century $^{18}$.

The only people in the house are the Frenchman and his butler, a young Arab named Samir, a native of Hodeidah in North Yemen. They hardly communicate with each other, but from time to time they watch each other through a mirror located in the room. The streams of consciousness of the Frenchman and Samir make up the content of the entire episode; there is practically no action as such. What these two streams of consciousness have in common is a sense of personal failure and fear of the uncertain future. In the morning, Samir does not find the Frenchman in the house and leaves the house.

The content of the second storyline is Samir's personal life in Aden, where he moved from Hodeidah shortly after the start of the civil war in North Yemen and the death of

17 About this manner in Steamer Point see [13; 14]. About his other novels: Status Correction (Tașhīh wad', 2004) American Coffee (Qahwa amīrkiyya, 2007), and War under the Skin (Harb taht al-jild, 2010) see [6, p. 259-260; 8, p. 88-90;12].

${ }_{18}$ Numerous details of the Frenchman's biography in the novel (p. 62-63, 73, 108-109, 149-150, 154-156) correspond to the biography of A. Besse, although the latter died sixteen years before the British left Aden. 
his father in this war. In Aden, Samir communicates with a middle-aged Englishwoman named Iris, with a group of young Aden Arabs, including his beloved Su'ad and a radical nationalist Najib, with his grandmother, with her elderly brother, and with some other people.

The main intrigue in this line is the gradual worsening of Samir's relations with Suad and the other members of the youth company due to his sympathy for the British, which is expressed, among other things, in the play he writes for school staging, devoted to captain Haines, the founder of Aden Colony. The final breakdown of his relations with Su'ad and the fear of being killed as a "henchman of the British" is what occupies his thoughts on the night before the British withdrawal from Aden.

While Samir is a "black sheep" among young Arabs because of his sympathy for the British, Iris is a "black sheep" among the British because of his sympathy for Arabs. Iris had come to Aden with her officer husband before WWII, with a desire to study the influence of Aden's cosmopolitan environment on the minds and mores of her countrymen. When her husband was assigned to East Africa, she divorced him and stayed in Aden. Though she had love affairs with some influential members of the European community of Aden, including the Frenchman (erotic scenes with her participation help to recreate in the novel the atmosphere of freedom inherent in Aden Colony), she became best known for her sharp criticism of the European, and especially British, attitude to Arabs as second-rate people. It was the Frenchman, with whom Iris had long since broken off the love affair, who recommended Samir to her as a teacher of Arabic - in order to continue to be aware of her personal life. Iris leaves Aden on the morning of November 28, 1967.

The reader can easily notice that the author obviously sympathizes with these two "black sheep".

The third storyline presents the story of an Adeni Arab named Qasim, which covers the period from the beginning of WWII until the British withdrawal from Aden. During the war, Qasim was engaged in smuggling goods from Aden to the neighboring areas ${ }^{19}$. His security in this business was provided by a high-ranking officer of the British RAF, whom Qasim paid back by delivering local whores to his house. One of those girls stayed in the officer's house for a long time, and on behalf of the officer, Qasim was taking the girl to shops, cinemas and cafes while the officer was on duty. Very soon, Qasim fell in love with the girl and was looking forward to every meeting with her. However, the officer was transferred from Aden to another place of service, and the girl disappeared. Unable to forget the girl, Qasim began searching for her. He was scouring street after street, quarter after quarter, inquiring with local people and whoever he met. After the war, Qasim became the owner of a coffee shop, but continued to devote all his leisure time to searching for the girl. The search geography was expanding as the city's population grew and many new suburbs emerged. By the end of the novel, Qasim is about fifty years old. He realizes that he will never marry and will not find his beloved. Subconsciously, he associates the tragedy of his personal life with that British officer, which makes him dislike all the British. This dislike is manifested, in particular, in the fact that he expels Arabs working as informants of the British security from his coffee shop. The deep psychological insight inherent in all Ahmad Zayn's works made this storyline in Steamer Point one of the best stories of a man's tragic love in the whole Yemeni literature.

19 Smuggling, in which many Adenis were involved during the war, is well described in the novel "Diary of a smuggler" (Yawmiyyāt mubarshit, 1948) by al-Tayyib Arslan. About this novel see [6, p. 61-63]. 
In the second and third storylines, there are also minor characters whose life stories significantly expand and elaborate the picture of the socio-political, economic and cultural life of not only Aden Colony, but to some extent the entire South Arabia.

In all three storylines, the narrative is filled with detail relating to the infrastructure of the city (districts, quarters, streets, hotels, restaurants, nightclubs, shops, pharmacies, transport), to its economy (port, oil refineries, international companies and banks, imported goods and their advertising in the media, tourist services, private businesses of well-known Adeni entrepreneurs), social and cultural life (cultural clubs, local newspapers, radio and television, cinemas and films, popular singers and musicians, horse racing, football and field hockey, fashion in clothing), ethnography (local cuisine, the types of dance, visiting the tomb of an Adeni saint Abu Bakr al-Aydarus). The memories of some characters relate to the pre-WWII history of the urban infrastructure and urban services in Aden, such as postal service and the railway. Especially many details of the economic and commercial life of the city appear in the memoirs of the Frenchman. Here is a fragment of such a kind ${ }^{20}$ :

"In the 1920s, when Aden, after the construction of Anglo-Persian Oil Company's storage facilities, turned into a supply point for oil tankers, he engaged in large imports of engine oil and coal from Iraq and Suez, required for ships anchoring in Aden. Before that, he was a trader in leather and hides, which he exported from Ethiopia, Somalia, the Arab countries, and India and delivered to America and Europe. To Aden, he imported coffee, frankincense, myrrh, and mint. Also he traded in wax, asafoetida, and dates. From Yemen and the Protectorates, he brought honey, aloe, oil, garlic, and cattle. From India, he imported various foods, dry beans, spices, from Java - sugar, from Zanzibar - cloves, from Singapore - pineapples, dry ginger, and cinnamon. After WWII, he founded an airline and began importing automobiles, electrical, photographic, and refrigeration equipment. When TV broadcasting started in Aden, for the first time in the entire region, he was the first to import TV-sets" [15, p. 64-65].

In the form of the characters' memoirs, the writer gives brief but vivid descriptions of visits to Aden by famous public and political figures of the $20^{\text {th }}$ century, such as Saad Zaghloul in 1922, Mahatma Gandhi in 1930, Prince Ahmad of North Yemen in 1946, Queen Elizabeth II in 1954.

Most attention in the novel is given to the socio-political processes and events of the post-WWII period, especially of the 1960s. Here are clashes between Arabs and Jews in Aden and Jews' emigration to Israel in 1949, the youth movement for the abolition of hijab and adoption of a new style in clothing, the formation of Aden trade unions and workers' strikes, the accession of Aden Colony to the Federation of South Arabia and NLF's guerrilla war against the British, the bloody conflict between NLF and FLOSY.

Impressions and memories of the characters in the novel form a vivid "visual" image of Aden Colony, of its street and public life in the periods before, during, and after WWII. The following three fragments of the novel give a clear idea of this.

Here is a scene that takes place in Crater in 1944:

${ }^{20}$ In the main episode of the novel, the author randomly changes the mode of the narration, suddenly switching from the third-person narration to the first-person (of Samir or the Frenchman), or from the firstperson narration to the second-person (in the form of Samir's or the Frenchman's addressing himself), etc. This can be seen in the fragments cited below. 
"He saw him from afar and suddenly felt a slight chill run through his body. He appeared out of the gloom, behind several camels loaded with goods: coffee, hides, honey, and tobacco from the Protectorates surrounding Aden. The camels were being unloaded on the spot behind the coffee shop. Having removed the bundles, which were thin because of wartime, the drivers took the camels aside to give them forage and water, and then disappeared inside the coffee shop. After a time these camels will go back through the same mountain pass, loaded with spices, rice, flour, and cloth, if any are available.

He pushed the swarming thoughts from his mind and stared at the pale, dusty lights of lanterns set up at the intersections of alleyways, resembling tired eyes. Colorless walls, the buzzing of flies landing on the eyes of an old dusty dog lying next to broken tables. Endless monotony, women wrapped in veils, naked children walking between wooden tables of irregular design, finishing tea after the customers and picking up sesame seeds. Somalis playing dominoes. The intermittent voice of Sayyid Husayn, preaching a sermon in front of the mosque in condemnation of Abu al-Tayyib al-Mutanabbi Camp ${ }^{21}$, criticizing the call of this club and its members for the liberation of women and the abolition of hijab.

Sitting on a long wooden bench designed for three people, he can easily imagine where each of the unpaved streets leads, and where ends each narrow alleyway in the quarters of Crater, divided according to the nationality of their inhabitants. One quarter is for Hindus, another for Jews, a third for Persians, a fourth for the British and other Europeans, and a fifth for Adeni Arabs and migrants from North Yemen and the Protectorates.

While watching the approaching figure of his friend, he heard a voice say, 'Even this newspaper writes only about the Allies' victories!'

He looked around and saw an Adeni Indian, whose father had come with captain Haines, stayed in Aden, and married a girl from the province of Taizz. The Indian was holding an issue of 'Fatat al-Jazira'22 in his hand. An oppositionist to the Imam's regime in North Yemen, who had fled with other opposition members to Aden, where they continued their struggle, agreed that the British were behaving like mad: the day before they arrested a merchant, who was selling aspirin tablets produced by German company Bayer, and accused him of Nazism. Someone else started talking about the Allied landing in Normandy, and how hundreds of them were killed before the operation was completed" $[15$, p. 41-42].

And this is how migrants from North Yemeni see Crater in the mid-1960s:

"Qasim is watching the workers and visitors, who stare at the Long-street with shops on both sides of it, selling electrical appliances, cosmetics, clothing and perfumes, with the feeling that they are experiencing some kind of miracles that come one after another and do not end. They like to name each miracle by the year in which it appeared. In their letters to their families, which they do not write themselves because they are illiterate and cannot read or write, they tell about television, cinemas, cameras, air conditioners, refrigerators, gas stoves, cars, and the blond women who drive these cars - as if they were discovering new, unseen things in this life. They also tell them about Coca-Cola, Green Fruit, and Canada Dry drinks, feeling proud that they know these things and have tasted them themselves" [15, p. 134-135].

${ }^{21}$ Abu al-Tayyib al-Mutanabbi Camp (mukhayyam) is the name of a cultural club, founded in Steamer Point in 1939 under the patronage of Muhammad Ali Luqman (note by M. Suvorov).

22 "Fatat al-Jazira" is the first Adeni non-governmental Arabic newspaper, founded be Muhammad Ali Luqman in 1940. About this newspaper see [6, p.46-48] (note by M. Suvorov). 
And the following scene takes place in Steamer Point, also in the mid-1960s:

"As if taken by surprise, Su'ad turned to him and saw that he was looking at something from which she herself had just been able to take her eyes off. It didn't even occur to her to wonder at the lack of people around who might have been curious enough to stare at a naked woman. Samir was surprised by what he saw - not because he was a man who craved female flesh out of instinct, but because he had never thought that he would encounter such a sight anywhere at all, except Aden.

It was not the huge cruise liner looking like a floating city that caught their attention and made them stare, but a scene taking place on the deck of one of the floors, which they considered extremely bold. The deck was very long, with dozens of windows looking out on the sea quays, on nearby hotels, on cinemas, modern cafes, bars and nightclubs, on shops selling watches, cameras, jewelry made of gold and silver, fashionable clothing, on the Queen Victoria shined monument, located in the spacious garden. The coffee shop was not too close, but it gave a good view of the wharf and the huge ships at anchor. Besides, her body, this European, glistened under the playful rays of the sun. At first Su'ad thought it was a man, and she wanted to look away, but the long hair combed up and the big breasts, which quivered slightly, made her look more closely. Anyway, Su'ad did not condemn the woman for this half-naked appearance, either because the latter was in the unbearable sun, while Su'ad viewed her through the glass of the air-conditioned coffee shop, or because such a spectacle can be expected from tourists, especially in this European district" [15, p. 77-78].

Unlike al-Muqri, Ahmad Zayn created in his novel an absolutely realistic, unadorned image of Aden Colony at various stages of its development in the $20^{\text {th }}$ century, an image, very similar to what one can see in D. Foster's memoirs. And this realistic image allows the reader to draw three conclusions.

First, as a British colony, Aden developed dynamically, comprehensively and in the right direction, attracting both rich entrepreneurs from all over the East and West, and cheap labor force from all over the South of Arabia.

Secondly, until 1967, the city remained the most economically and culturally flourishing of all the cities of the Arabian Peninsula, which, of course, provided a fairly high standard of living for native Adenis, as well as subsistence for thousands of poor migrants from other parts of South Arabia.

Third, all this prosperity ended almost instantly in the end of 1967, and the current state of Aden compared with its state in the late colonial times can only be described as degradation and decline. Aden of today in comparison to other major cities of the Arabian Peninsula looks about the same as Hodeidah in the novel looked in comparison to Aden Colony.

Unlike the characters of al-Muqri's novel, who hardly express any clear attitude to the political events of the 1960s, the characters of Steamer Point are extremely concerned about what is happening in Aden in this period. Since it is the inner worlds of Samir and the Frenchman that are most open to the reader, it is their attitudes to those events that form the reader's understanding of what really happened. The following fragments of Samir's internal monologue and stream of consciousness show what he thinks about Aden Colony, the British, and the revolutionaries:

"Aden shocked you. It was merciless to your feelings when, in an instant, it showed you all that it had in itself. To you, who came from a town of dusty color and earthy fea- 
tures. Before that, you only saw modern cities in pictures, but Aden appeared a city that simply had no equal. At first glance, it seemed to me a piece of Paradise. And I whispered to myself, 'I am Adeni!' Because I felt I didn't want to live in any city other than Aden" [15, p. 19].

"I wanted to hate them ${ }^{23}$, but I couldn't. I like their way of life. And every other time I find that I like more and more what they did in this city. They did it not only for themselves, but even if only for themselves, as some claim, can't we get our share of the benefit of it all in some way? Whether we are Adenis or not in the British eyes, does not matter. The most important is what we feel ourselves. Unfortunately, for some reason we do not listen to ourselves, but listen to other people's voices, loud and sharp, more like machine-gun fire and the roar of explosions" [15, p. 81].

"Your only hope and your unequivocal desire is that Aden remains open to all, that when you wake up one day, you will not find the city closed to the outside world. Your controversy with Najib escalated when you began to doubt the ability of revolutionaries, who are at war with each other, to lead Aden to new prosperity. You really looked with pessimism at the partisans, who began to exterminate each other only because they don't will, in your opinion, to share power with anyone. Even towards the British, they did not show such brutality as they do when fighting each other" [15, p. 161].

"I will not say that I have never seen the British kicking with their boots and hitting with rifle butts people who did nothing to them, but simply said, 'Get out of our city!' They throw them, half-naked, on the asphalt in the middle of the day, when the sun is hot as hell, so that it seems to me that I smell fried human meat. But I have also seen our fellow men turn into beasts of prey, into bloodthirsty wolves, hungry for each other's flesh, and I have seen armed groups pounce on each other, wait for the slightest misstep of their opponents and enemies, hunt them at night" [15, p. 71].

"As for me, I have no desire to accuse anyone of treason. I came like a dead man from Hodeidah, a faceless city, which keeps now only silence and memories, and the corpses of soldiers: Egyptians and Yemenis, monarchists and Republicans. I don't want to go back there after I found my real life in Aden" [15, p. 18].

It is worth noting that Samir is not the only character in Yemeni literature to dislike South Yemeni revolutionaries ${ }^{24}$, but he is the first and so far the only protagonist in this literature who is openly sympathetic to the British.

The three novels discussed above differ in their depiction of Aden Colony and the place it occupies in the narrative.

In the novel Three Midnighters, which takes place in post-colonial times, the image of Aden Colony as such is absent. There are only memories of the characters about the activities of an Adeni cultural club, which serves in the novel as an allegory of Aden Colony. The main characteristics of that club were its openness to all people, its atmosphere of freedom of thought, freedom of expression, mutual respect of its members, prosperity, love, and fun.

${ }^{23}$ He speaks about the British (note by M. Suvorov).

24 This attitude to the revolutionaries can be found, for instance, in the novels The Ruined Queen (al-Malika al-maghdūra, 2002) and Revelation (Waḥ, 2018) by Habib Saruri. 
In Adeni Incense, Aden Colony also resembles a wonderful club that has exactly the same characteristics as the club in Three Midnighters. The members of this club, that is, the characters of the novel, who belong to a variety of nationalities and faiths, live in harmony, love and prosperity - until evil external forces, whose essence remains virtually outside the framework of the story, begin to destroy this club. Although some of the events described in the novel correspond to what was going in Aden Colony in the 1940-60s, the lack of realistic details in the depiction of the city and its inhabitants makes the novel not less allegorical than realistic.

It is noteworthy that in both Three Midnighters and Adeni Incense there is no clear image of the forces that destroyed this wonderful club.

In Steamer Point, Aden Colony does not appear in any period of its history as a wonderful club, since the novel is written in a completely realistic manner. Nevertheless, the Aden portrayed by Ahmad Zayn has two important features, the impending loss of which makes the two main characters grieve. The first feature is economic prosperity, which distinguishes Aden from other cities of the Arabian Peninsula. The second feature is peaceful coexistence of representatives of different cultures and different identities, who feel free to manifest their views and beliefs. The evil forces that deprive the city of these features are well defined in the novel: they are people of a certain mentality and certain beliefs.

The two mentioned features, which are also characteristic of Sa'id Awlaqi's and Ali alMuqri's "clubs", and which are discussed in K. A. Davis's study of Adenis' collective memory, are undoubtedly the two main reasons for Adenis' nostalgia for the colonial times. Interestingly, of all three authors, only Sa'id Awlaqi, a native Adeni, is a living witness to the life of Aden Colony. The other two writers were born in the last years of its existence and are not natives of Aden ${ }^{25}$. For this reason, their literary interest to Aden Colony may be considered an indirect evidence of the fact that cultural diversity and economic prosperity are something that all Yemenis, especially intellectuals, are in urgent need of today.

\section{References}

1. El-Enany R. Arab Representations of the Occident. East-West Encounters in Arabic Fiction. New York, Routledge, 2006. 255 p.

2. Della Dora V. The rhetoric of nostalgia: postcolonial Alexandria between uncanny memories and global geographies. Cultural geographies, SAGE Publications, 2006, 13 (2), pp. 207-238.

3. Davis K. A. From Collective Memory to Nationalism: Historical Remembrance in Aden. A Thesis submitted to the Faculty of the Graduate School of Arts and Sciences of Georgetown University in partial fulfillment of the requirements for the degree of Master of Arts in Arab Studies. Washington, DC April 31, 2014 (MS). Available at: https://repository.library.georgetown.edu/bitstream/handle/10822/709719/Davis_georgetown_0076M_12671.pdf?sequence=1\&isAllowed=y (accessed: 09.07.2020).

4. Dresch P. A History of Modern Yemen. UK, Cambridge University Press, 2000. 285 p.

5. Clark V. Yemen: Dancing on the Heads of Snakes. Hampshire: Yale University Press, 2010. 311 p.

6. Suvorov M. N. Yemeni prose fiction (1940 - mid-2000s). St. Petersburg: Studiya "NP-Print", 2010. 359 p. (In Russian)

7. 'Awlaqī, Sa'ìd. Three Midnighters. Sanaa: Markaz 'Ubādī li-l-dirāsāt wa-l-nashr, 1993. 112 p. (In Arabic)

8. Suvorov M.N. "Big" prose in Yemen in the second half of the 2000s. Vestnik of Saint Petersburg University. Ser. 13, 2010, issue 4, pp. 83-91. (In Russian)

${ }^{25}$ Ali al-Muqri is native of Taizz province, and Ahmad Zayn — of Hodeidah. 
9. Suvorov M. N. New Novels from Yemen: Between Revelation and Epatage. Vestnik of Saint Petersburg University. Ser. 13, 2013, issue 4, pp. 68-78. (In Russian)

10. Foster D. Landscape with Arabs: Travels in Aden and South Arabia. Clifton books Brighton and London, 1969. $216 \mathrm{p}$.

11. al-Muqrī, 'Alī. Adeni Incense. Beirut: Dār al-sāqī, 2014. 335 p. (In Arabic)

12. Suvorov M.N. Two Novels about the Information War in Yemen on the Eve of the Revolution of 2011. Vestnik of Saint Petersburg University. Ser. 13, 2019, issue 3, pp. 298-310.

13. 'Allām, Fā'iz. An Overview of the Novel 'Steamer Point'. Available at: https://raseef22.com/article/28828-steamer-point-book-review (accessed: 09.07.2020) (In Arabic)

14. al-Shaybānī, Muḥammad 'Abd al-Wahhāb. The British Aden Shatters in the Mirror of Reality: The Novel 'Steamer Point' by Ahmad Zayn. Available at: https://langue-arabe.fr/\%D8\%B3\%D8\%AA\%D9\%8A\%D9\% 85\%D8\%B1-\%D8\%A8\%D9\%88\%D9\%8A\%D9\%86\%D8\%AA-\%D8\%A3\%D8\%AD\%D9\%85\%D8\%AF\%D8\%B2\%D9\%8A\%D9\%86-\%D8\%A7\%D9\%84\%D9\%8A\%D9\%85\%D9\%86-\%D8\%B1\%D9\%88\% D8\%A7\%D9\%8A\%D8\%A9 (accessed: 09.07.2020). (In Arabic)

15. Zayn A. Steamer Point. Cairo: al-Hay'a al-mișriyya al-āmma li-l-kitāb, 2017. 256 p. (In Arabic)

Received: July 27,2020 Accepted: December 28, 2020

Author's information:

Mikhail N.Suvorov — Dr. Sci. in Philology, Professor; soumike@mail.ru

\title{
Колониальный Аден в постколониальном йеменском романе
}

\author{
М. Н. Суворов \\ Санкт-Петербургский государственный университет, \\ Российская Федерация, 199034, Санкт-Петербург, Университетская наб., 7-9
}

Для цитирования: Suvorov M. N. The Colony of Aden in Post-Colonial Yemeni Novel // Вестник Санкт-Петербургского университета. Востоковедение и африканистика. 2021. Т. 13. Вып. 1. C. 32-50. https://doi.org/10.21638/spbu13.2021.103

Во многих арабских странах, где на смену колониальному правлению пришли местные авторитарные, часто коррумпированные режимы, недовольство населения условиями жизни при новой власти породило своего рода ностальгию по колониальному прошлому. Эта ностальгия в настоящее время наблюдается в Адене (Йеменская Республика), который с 1839 по 1967 г. был колонией Великобритании и в середине XX в. самым процветающим городом на Аравийском полуострове, одним из самых оживленных морских портов в мире. В настоящей статье рассматривается выражение этой ностальгии в современной литературе Йемена, а именно в трех романах: «Трое полуночников» (1993) Саида Аулаки, «Аденские благовония» (2014) Али ал-Мукри и «Стимер-пойнт» (2015) Ахмада Зейна. В романе «Трое полуночников» действие происходит в конце 1980-х годов. Аллегорией колониального Адена служит культурный клуб, о деятельности которого вспоминают герои. Главными чертами этого клуба были его открытость для всех людей, атмосфера свободы мысли и самовыражения, взаимоуважения его членов, процветания, любви и веселья. В романе «Аденские благовония» колониальный Аден также напоминает чудесный клуб. Члены этого клуба, т. е. герои романа, живут в согласии, любви и благополучии до тех пор, пока внешние злые силы не начинают разрушать этот клуб. Недостаток реалистических деталей в изображении города и его жителей делает роман более аллегорическим, чем реалистическим. В романе «Стимерпойнт» колониальный Аден не выглядит чудесным клубом, поскольку роман написан 
в абсолютно реалистической манере. Однако Аден здесь имеет две важные черты: экономическое процветание и мирное сосуществование представителей разных культур и разных идентичностей. Именно этих черт города один из главных героев, искренний почитатель англичан, боится лишиться в результате ухода последних.

Ключевые слова: арабский роман, Йемен, Аден, Саид Аулаки, Али ал-Мукри, Ахмад Зейн.

Статья поступила в редакцию 19 июля 2020 г., рекомендована к печати 28 декабря 2020 г.

Контактная информация:

Суворов Михаил Николаевич — д-р филол. наук, проф.; soumike@mail.ru 